Ekspansi: Jurnal Ekonomi, Keuangan, Perbankan dan Akuntansi

ISSN (Online): 2580-7668 ISSN (Print): 2085-5230

Vol. 13, No. 1 (Mei 2021), Hal. 32 - 45

\title{
PERAN AUDIT FEE DAN FAKTOR YANG MEMPENGARUHI KUALITAS AUDIT
}

\author{
Zalfa Shafira Qatrunnada ${ }^{1}$, Siti Sundari ${ }^{2}$ \\ 1,2 Universitas Pembangunan Nasional "Veteran” Jawa Timur, Surabaya, Indonesia \\ Email Korespondensi: zalfashafira300@gmail.com
}

\begin{abstract}
This research aimed to obtain empirical evidence regarding factors that influence audit quality, such as the audit firm reputation, audit tenure, and auditor switching with audit fees as the moderating in manufacturing companies consumer goods industry sector listed on the Indonesia Stock Exchange (IDX) in 2015-2019. The research sample consisted of 115 observations which were determined by purposive sampling technique. This study used logistic regression analysis with SPSS v.26 as an analysis technique. The result showed that audit firm reputation has no significant effect on audit quality, audit tenure has a positive and significant effect on audit quality, auditor switching has no significant effect on audit quality, audit fees are not moderate the effect of audit firm reputation on audit quality, audit fees are weakening the effect of audit tenure on audit quality, and audit fees are not moderate the effect of auditor switching on audit quality.
\end{abstract}

Keywords: Audit Quality, Audit Firm Reputation, Audit Tenure, Auditor Switching, Audit Fee

Abstrak: Penelitian ini bertujuan untuk memperoleh bukti empiris mengenai sejumlah faktor yang memberikan pengaruh terhadap kualitas audit seperti reputasi KAP, audit tenure dan auditor switching dengan audit fee sebagai pemoderasi pada perusahaan manufaktur bidang industri barang konsumsi yang terdaftar pada Bursa Efek Indonesia periode tahun 2015-2019. Sampel penelitian berjumlah 115 pengamatan yang ditetapkan dengan metode purposive sampling. Analisis data menggunakan regresi logistic dengan memanfatkan perangkat lunak SPSS v.26. Hasil penelitian menunjukkan audit tenure berpengaruh positif dan signifikan terhadap kualitas audit, sedangkan reputasi KAP dan auditor switching tidak berpengaruh signifikan terhadap kualitas audit. Selain itu, audit fee memperlemah pengaruh audit tenure terhadap kualitas audit, namun audit fee tidak mampu memoderasi pengaruh auditor switching dan reputasi KAP terhadap kualitas audit.

Kata Kunci: Kualitas Audit, Reputasi KAP, Audit Tenure, Auditor Switching, Audit Fee 


\section{PENDAHULUAN}

Persaingan dalam dunia bisnis yang semakin ketat dan timbul banyaknya perusahaan yang melakukan go public menjadikan kebutuhan akan jasa akuntan publik untuk menghasilkan laporan keuangan yang berkualitas untuk menunjang para pemakai informasi dalam pengambilan keputusan akan semakin meningkat (Pertamy \& Lestari, 2018). Pelaksanaan penugasan audit oleh auditor harus didasarkan pada standar audit maupun kode etik profesi yang berlaku agar independensi auditor tetap terjaga dan senantiasa bertindak secara professional sehingga dapat meningkatkan kepercayaan masyarakat umum khususnya pengguna informasi keuangan terhadap jasa pelayanan akuntan publik (Agoes, 2017). Namun realitanya, di Indonesia masih terdapat kasus mengenai kegagalan auditor menerapkan kode etik tersebut dalam melaksanakan penugasan audit, contohnya kasus pada Kantor Akuntan Publik (KAP) Purwanto, Suherman dan Surja serta Ernst and Young (EY) Indonesia sebagai partner gagal menyajikan bukti pendukung terkait perhitungan sewa atas 4.000 menara seluler pada laporan keuangan (Kontan, 2017). Akuntan Publik (AP) Sherly Jokom, anggota KAP EY Global Limited yang melakukan manipulasi penyajian laporan keuangan PT Hanson Internasional tahun 2016 terkait penjualan kavling siap bangun (Kompas, 2020). Serta kasus AP Kasner Sirumapea anggota KAP Tanubrata, Sutanto, Fahmi dan Rekan yang melakukan kelalaian dalam penugasan audit laporan keuangan PT. Garuda Indonesia tahun 2018 yakni belum secara tepat menilai transaksi akuntansi atas pengakuan pendapatan piutang dan pendapatan lain-lain, belum secara penuh memperoleh bukti audit yang cukup, serta tidak dapat meninjau fakta-fakta setelah tanggal laporan keuangan sebagai dasar perlakuan akuntansi (CNN Indonesia, 2019).

Skandal yang melibatkan KAP besar tersebut menimbulkan pertanyaan mengenai independensi dan kompetensi auditor dalam melaksanakan penugasan audit sehingga dapat menurunkan keyakinan publik terhadap kualitas audit yang dihasilkan. Pentingnya suatu kualitas audit ditujukan untuk mempertahankan keyakinan publik terhadap validitas dan akurasi laporan keuangan dikarenakan kualitas dalam audit menjadi kemungkinan bagi pihak auditor untuk memiliki kemampuan dalam mendeteksi maupun pengungkapan terhadap suatu pelanggaran ataupun salah saji dalam laporan keuangan ketika sedang melaksanakan tahapan audit (De Angelo, 1981). Kualitas hasil audit dapat dipengaruhi oleh adanya aspek eksternal seperti reputasi KAP, audit tenure, auditor switching dan audit fee.

Reputasi sebuah KAP sering dihubungkan dengan ukuran KAP sehingga semakin besarnya ukuran KAP maka mengindikasikan adanya independensi dan profesionalisme auditor dalam melaksanakan audit (Pertamy \& Lestari, 2018). Semakin tinggi nilai reputasi KAP maka kemampuan auditor dalam melaksanakan audit akan makin besar sehingga hasil dari kualitas audit dapat makin besar pula (Prasetya \& Rozali, 2016). Namun hasil penelitian Irma et al., (2019) yang menyatakan bahwa baik KAP BigFour maupun nonBigFour akan tetap menghasilkan kualitas audit yang tinggi sebab mereka tetap bersikap objektif dengan tetap mengungkapkan keadaan sesungguh atas laporan keuangan auditee. 
Audit tenure atau fase ikatan audit dari KAP dengan auditee juga bisa memberikan pengaruh terhadap kualitas auditnya. Masa perikatan KAP dengan auditee yang semakin lama akan meningkatkan kompetensi auditor dan pemahaman auditor mengenai kondisi bisnis auditee akan semakin tinggi (Pertamy \& Lestari, 2018). Menurut Ardani (2017), lamanya masa perikatan akan meningkatkan kualitas hasil audit dikarenakan kompetensi yang dimiliki auditor dapat digunakan sebagai dasar pengambilan keputusan audit. Disamping itu, direvisinya peraturan mengenai pembatasan pemberian jasa audit yang ditujukan hanya untuk auditor yang dicantumkan pada PP Nomor 20/2015 pasal 11, maka pihak auditee dapat mempertimbangkan untuk melakukan perikatan dengan KAP dengan jangka waktu yang lama agar kualitas audit yang dihasilkan dapat lebih tinggi. Lain halnya penelitian Rahmi et al., (2019) dipaparkan jika lama masa ikatan audit dapat menimbulkan adanya kedekatan antara pihak KAP dan auditee sehingga independensi dari auditor maupun kualitas audit dapat terus menurun.

Ikatan Akuntan Indonesia mengharuskan agar auditor switching dapat diberlakukan sehingga terjadinya skandal yang menimpa KAP dapat diminimalisir (Nizar, 2017). Perotasian dilakukan berdasarkan PP Nomor 20/2015 pasal 11 yakni auditor dalam memberikan layanan audit umum terhadap pelaporan keuangan entitas yang terlama yaitu 5 tahun buku berturut-turut, yang dilakukan agar independensi auditor tetap terjaga selama pemberian jasa audit yang dapat meningkatkan kualitas hasil audit (Dwiyani \& Rasmini, 2017). Peraturan rotasi juga dibuat berdasarkan pada asumsi semakin lama perikatan antara auditor dan auditee maka dapat menurunkan independensi auditor sehingga ditujukan untuk meningkatkan kualitas audit karena masa perikatan auditor dan auditee dapat dibatasi (Ishak \& Perdana, 2015). Namun menurut (Rahmi, et al. 2019), kecenderungan dilakukannya rotasi auditor oleh perusahaan disebabkan adanya ketidakpuasan dan ketidaksesuaian auditor dalam pelaksanaan auditnya sehingga tidak adanya pengaruh dari auditor switching terhadap kualitas audit.

Adapun faktor lain yang dapat memberikan pengaruh terhadap kualitas dari audit yakni audit fee. Audit fee atau biaya audit adalah balasan layanan yang didapatkan dari pihak audit atas jasa audit yang telah dilaksanakan. Biaya untuk audit selain ditentukan dengan berdasarkan pada jasa yang telah diberikan oleh pihak auditor, juga ditentukan dengan berdasarkan pada kebutuhan klien, tingkat keahlian auditor serta lamanya penyelesaian yang diperlukan untuk mengaudit (Novrilia et al., 2019). Menurut Ardani (2017), tingginya audit fee akan meningkatkan hasil dari kualitas audit yang dilakukan auditor dikarenakan telah terciptanya kualitas audit dengan sebaik-baiknya yang diberikan pengaruh oleh kinerja pihak auditor yang professional selama pelaksanaan audit atas laporan keuangan auditee. Hasil lain ditunjukkan pada penelitian Ramadhan \& Laksito (2018) yang menyatakan bahwa tingginya biaya audit dapat menurunkan independensi auditor dikarenakan dapat menghambat auditor untuk menolak keinginan klien.

Adanya fenomena kegagalan auditor dalam pelaksanaan penugasan audit dan inkonsistensi hasil penelitian terdahulu mengenai faktor-faktor yang mempengaruhi 
kualitas audit, maka peneliti tertarik untuk melakukan riset untuk mengkaji ulang sejumlah faktor eskternal seperti reputasi KAP, audit tenure, auditor switching serta menambahkan variabel audit fee sebagai pemoderasi apakah dapat mempengaruhi kualitas hasil audit atas penugasan audit laporan keuangan auditee. Penelitian ini diharapkan dapat bermanfaat bagi auditor untuk tetap memperhatikan faktor eksternal yang dapat berpengaruh terhadap kualitas audit sehingga kualitas audit yang dihasilkan tidak diragukan dan dapat bermanfaat bagi pengguna informasi dalam pengambilan keputusan.

Perusahaan manufaktur yang bergerak pada bidang industri barang konsumsi digunakan sebagai subjek dalam studi ini, dikarenakan perusahaan tersebut memegang peran penting dalam pertumbuhan suatu Negara sebagai salah satu penyumbang terbesar dalam perekonomian negara dimana berdasarkan PDB tahun 2019 bidang industri barang konsumsi berkontribusi sebesar 9,7\% dan pada tahun 2020 sebesar 10,1\% (Badan Pusat Statistik, n.d.). Selain itu, menurut Nadya (2020) meskipun terjadi penurunan kinerja saham pada kuartal I tahun 2020 sebesar 19,17\% namun koreksi kinerja saham pada bidang barang konsumsi lebih kecil dari indeks sektor lain. Sehingga, menandakan bahwa saham pada bidang barang konsumsi cenderung lebih kokoh serta sektor yang paling defensive saat terjadi resesi maupun krisis meskipun tidak dapat berkembang tinggi saat perekonomian sedang berkembang dengan pesat (Kontan, n.d.).

\section{TINJAUAN PUSTAKA}

Secara konseptual teori keagenan ialah ikatan maupun kontrak dari pemilik ataupun principle serta manajemen ataupun agent. Berdasarkan pemaparan dari Jensen \& Meckling (1976) bahwa teori keagenan sebagai suatu perikatan yang meliputi 1 ataupun lebih dari individu yang berperan sebagai pemilik terhadap individu lainnya yang berperan sebagai agen pengelola untuk menggunakan layanan berdasarkan kepentingannya yang mana melibatkan penyerahan pengambilan keputusan kepada pihak agen pengelola dengan fungsi sebagai manajemen. Pembahasan dalam teori keagenan banyak menekankan pada permasalahan-permasalahan kemungkinan terjadinya konflik kepentingan serta kesalahpahaman atau asimetri informasi pada kedua belah pihak akibat timbulnya suatu motivasi dari kepentingan pribadi manajemen yang tidak selalu bertindak sesuai dengan tujuan yang dimiliki oleh pemilik (Permatasari \& Astuti, 2018).

Asimetri informasi dan konflik kepentingan timbul disebabkan oleh kecenderungan antara prinsipal dan agen untuk mementingkan diri sendiri, sehingga, muncul suatu kebutuhan akan laporan keuangan yang terbebas oleh kesalahan penyajian dan kekurangan serta disesuaikan terhadap standar audit yang telah diberlakukan (Novrilia et al., 2019). Audit terhadap pelaporan keuangan yang telah dihasilkan dan disajikan oleh auditor akan memberikan suatu informasi yang sesungguhnya terkait dengan kondisi dari perusahaan sehingga dapat dilakukan upaya untuk mencegah timbulnya kesalahpahaman ataupun asimetri informasi dan membantu pihak principal dalam pengambilan keputusan. 
Kualitas audit dapat dideskripsikan dengan kemungkinan bagi auditor untuk memiliki kemampuan dalam mendeteksi suatu pelanggaran dalam sistem akuntansi auditee ketika pelaksanaan audit dan mengungkapkan pelanggaran tersebut dalam laporan keuangan auditan (De Angelo, 1981). Risiko penyajian informasi keuangan yang tidak relevan dan reliable dapat diminimalkan sehingga kredibilitas dan integritas laporan keuangan dapat ditingkatkan.

Reputasi KAP berhubungan dengan integritas yang dimiliki oleh auditor sebab KAP yang bereputasi tinggi memiliki tingkat kesanggupan yang mendalam dalam melaksanakan audit dengan demikian dapat diperoleh audit yang berkualitas baik dan dapat meningkatkan kepercayaan para pengguna informasi atas hasil audit yang telah didapatkan (Prasetya \& Rozali, 2016). Menurut Rizki (2020), auditee juga cenderung menunjuk auditor yang memiliki reputasi baik untuk melaksanakan audit atas laporan keuangannya sehingga hasil audit dapat lebih berkualitas dan dapat meningkatkan citra perusahaan dimata publik.

\section{$\mathrm{H}_{1}$ : Reputasi KAP berpengaruh terhadap kualitas audit.}

Audit tenure atau masa perikatan KAP dapat mempengaruhi kinerja auditor dalam melaksanakan audit dengan auditee seperti independensi, professionalism kerja, hubungan emosional auditor dengan klien dan kompetensi (Prasetya \& Rozali, 2016). Menurut Knapp (1991) dalam Dwiyani \& Rasmini (2017), jangka waktu yang terlalu singkat dalam perikatan, menjadikan masih rendahnya pengetahuan auditor mengenai kondisi perusahaan klien sehingga kualitas audit yang dihasilkan rendah. Oleh karena itu, lamanya masa perikatan antara KAP dengan auditee dapat memperdalam pengalaman serta wawasan dari auditor yang bisa dipergunakan dalam menyusun agenda audit dengan efektivitas serta menghasilkan laporan audit dengan kualitas yang tinggi (Nadia, 2015).

$\mathrm{H}_{2}$ : Audit tenure berpengaruh terhadap kualitas audit.

Menurut Muliawan \& Sujana (2017), apabila auditor melakukan perikatan dengan kliennya pada kurun waktu yang panjang, dapat berdampak pada berkurangnya independensi yang dimiliki auditor yang disebabkan dari penurunan objektivitas auditor selama masa perikatan tersebut. Di samping hal tersebut, terdapat Peraturan Pemerintah nomor 20/2015 pasal 11 di mana memberikan batasan dalam pemberian layanan audit terhadap laporan keuangan perusahaan dengan akuntan publik yang terlama selama 5 tahun ditujukan agar akuntan publik tersebut tetap menjaga independensi yang dimiliki dalam pemberian jasa audit kepada klien (Tuanakotta, 2015). Pelaksanaan auditor switching juga dapat memberikan insentif dalam menghadapi tekanan manajemen serta menjaga dan meningkatkan independensi auditor dalam pemberian jasa audit.

\section{$\mathrm{H}_{3}$ : Auditor switching berpengaruh terhadap kualitas audit.}

Audit fee atau biaya audit adalah balasan layanan yang didapatkan dari pihak audit atas jasa audit yang telah dilaksanakan. Suatu biaya audit dapat ditentukan berdasarkan tingkat keahlian auditor seperti komptensi dan pemahaman auditor mengenai kondisi bisnis auditee dalam memberikan jasa audit (Mulyadi, 2016). KAP yang berukuran besar (BigFour) umumnya mengindikasikan bahwa KAP tersebut bereputasi baik dan 
hasil dari audit yang diperoleh cenderung lebih tinggi dikarenakan adanya kompetensi dan pengetahuan yang lebih mendalam dimiliki pada auditor tersebut (Prasetya \& Rozali, 2016). Menurut Dwiyani \& Rasmini (2017) perusahaan cenderung memilih KAP yang bereputasi tinggi meskipun biaya audit yang ditawarkan lebih mahal dikarenakan kemampuan dan pemahaman auditor yang lebih baik dalam pemberian jasa audit serta memberikan opini audit secara actual terhadap kondisi bisnis auditee.

\section{$\mathrm{H}_{4}$ : Audit fee memperkuat pengaruh reputasi KAP terhadap kualitas audit.}

Suatu perikatan umumnya didasarkan oleh adanya suatu kontrak, salah satu isi kontrak tersebut tentunya terkait dengan fee yang diberikan kepada auditor atas jasa auditnya. Menurut Lee \& Sukartha (2017), KAP dengan biaya audit yang tinggi umumnya memiliki tingkat keahlian dan independensi yang tinggi dalam melaksanakan auditnya. Masa perikatan pada kurun waktu yang panjang dengan kliennya bisa meningkatkan keahlian dari auditor mengenai kondisi pada bisnis auditee dengan demikian bisa dihasilkan audit yang berkualitas lebih baik (Ardani, 2017). Auditor yang memiliki biaya audit cenderung tinggi memiliki keahlian yang juga memadai mengenai perusahaan auditee oleh karena itu auditor membutuhkan waku perikatan yang lama sehingga dapat menghasilkan laporan audit yang berkualitas (Lee \& Sukartha, 2017).

$\mathrm{H}_{5}$ : Audit fee memperkuat pengaruh audit tenure terhadap kualitas audit.

Kontrak yang dibuat pada suatu hubungan keagenan antara auditor dengan manajemen salah satunya mengenai pemberian biaya audit kepada auditor yang ditentukan berdasarkan kompleksitas perusahaan klien, risiko audit dan waktu yang diberikan (Lee \& Sukartha, 2017). Menurut Dwiyani \& Rasmini (2017), biaya audit yang tinggi dapat meningkatkan kualitas audit dikarenakan tingginya tingkat keahlian auditor dan risiko penugasan audit. Rotasi audit wajib dilakukan untuk menjaga independensi dan profesionalisme auditor dalam memberikan jasa auditnya. Selain itu, perusahaan biasanya melakukan rotasi audit untuk mendapatkan auditor yang berkemampuan tinggi dalam pelaksanaan penugasan sehingga laporan audit yang dihasilkan dapat berkualitas meskipun biaya audit yang ditawarkan jauh lebih mahal, dilain pihak, rotasi audit juga dilakukan jika perusahaan memliki masalah keuangan yang menyebabkan ketidaksanggupan perusahaan untuk membayar biaya audit yang tinggi (Dwiyani \& Rasmini, 2017).

$\mathrm{H}_{6}$ : Audit fee memperkuat pengaruh audit tenure terhadap kualitas audit.

\section{METODE PENELITIAN}

Penelitian ini memanfaatkan teknik menganalisis data berjenis kuantitatif yang memiliki tujuan melakukan pengujian terhadap hipotesis yang sudah ditentukan sebelumnya (Sugiyono, 2016). Perusahaan manufaktor bidang industri barang konsumsi yang berada pada daftar BEI mulai periode 2015 hingga 2019 digunakan sebagai subjek dalam penelitian dengan meninjau variabel kualitas audit, reputasi KAP, audit tenure, auditor switching serta audit fee sebagai objek penelitian. Penelitian ini memanfaatkan data berjenis sekunder yakni pelaporan keuangan tahunan dari instansi 
bisnis bidang perindustrian konsumsi pada periode 2015-2019 dan diperoleh lewat situs laman resmi dari BEI atau www.idx.co.id.

Reputasi KAP yang umumnya didasarkan pada ukuran sebuah KAP sehingga KAP yang berukuran besar diidentikkan dengan reputasi KAP yang tinggi dikarenakan investor beranggapan bahwa auditor dari KAP BigFour ataupun memiliki afiliasi terhadap KAP internasional yang berkualitas lebih baik (Nadia, 2015). Pengukuran reputasi KAP menggunakan variabel dummy dengan memberi skor 1 apabila KAP mempunyai afiliasi terhadap BigFour serta skor 0 apabila KAP mempunyai afiliasi terhadap non BigFour (Nizar, 2017).

Audit tenure didefinisikan sebagai masa keterlibatan dari KAP dengan kliennya berkaitan untuk memberi layanan audit yang sudah disetujui satu sama lain (Paputungan \& Kaluge, 2018). Pengukuran audit tenure memanfaatkan penggunaan skala interval dan diproksikan terhadap lama masa perikatan yang terjalin antara KAP dan kliennya yang dimulai pada angka 1 di tahun pertama perikatan dan tahun seterusnya (Hasanah \& Putri, 2018).

Auditor switching yakni melakukan pergantian auditor saat pemberian jasa audit pada auditee yang ditujukan untuk mempertahankan independensi dan profesionalisme auditor. Pengukuran auditor switching memanfaatkan penggunaan variabel dummy dengan memberikan skor 1 apabila terdapat pergantian dari auditor dan skor 0 apabila tidak terdapat pergantian dari auditornya (Irma et al., 2019).

De Angelo (1981) memaparkan definisi dari kualitas audit menjadi sesuatu kemungkinan bagi auditor dalam memiliki kemampuan agar mengungkapkan dan melakukan pendeteksian terhadap adanya pelanggaran atau kesalahan penyajian pada laporan keuangan ketika pelaksanaan audit sedang dilangsungkan. Kualitas dari audit diukur dengan menggunakan skala nominal disertai penggunaan earning benchmark yakni dari $p$-ct serta $p^{+} c t$, dimana $p$ merupakan rata-rata jumlah aset serta ct merupakan deviasi (Nizar, 2017). Sehingga:

Nilai 1 = kualitas audit tinggi jika $\mathrm{p}-\mathrm{n}<\mathrm{ROA}<\mathrm{p}+\mathrm{n}$

Nilai $0=$ kualitas audit rendah jika $R O A>p+n$ atau $R O A<p-n$

Audit fee didefinisikan sebagai imbal layanan yang diberikan kepada auditor atas layanan pelaporan keuangan auditee. Pengukuran audit fee menggunakan logaritma natural yang diproksikan dengan akun professional fee dan terdapat dalam pelaporan keuangan auditee (Lee \& Sukartha, 2017).

Sebanyak 54 perusahaan manufaktur pada bidang industri barang konsumsi yang terdaftar di BEI tahun 2015-2019 adalah populasi yang dipergunakan pada penelitian ini. Untuk menentukan sampel memanfaatkan penggunaan metode purposive sampling, dan diperoleh sampel sebanyak 115 sampel.

Tabel 1. Penetapan Sampel

\begin{tabular}{ccc}
\hline No. & Kriteria & Jumlah Perusahaan \\
\hline 1 & $\begin{array}{c}\text { Perusahaan manufaktur bidang industri barang konsumsi yang } \\
\text { terdaftar di Bursa Efek Indonesia (BEI) tahun 2015-2019. }\end{array}$ & 54 \\
& $\begin{array}{c}\text { Perusahaan yang tidak menyediakan laporan keuangan secara } \\
\text { lengkap periode 2015-2019. }\end{array}$
\end{tabular}




\begin{tabular}{ccc}
\hline No. & Kriteria & Jumlah Perusahaan \\
\hline 3 & Perusahaan yang tidak menyertakan akun professional fee. & $(15)$ \\
4 & Perusahaan yang tidak menggunakan mata uang Rupiah dalam & $(0)$ \\
& pelaporan keuangan. & 23 \\
\hline & Jumlah Sampel Akhir & 5 \\
Tahun Amatan & 115 \\
Jumlah Amatan &
\end{tabular}

Pengumpulan data dilaksanakan melalui metode dokumentasi yakni dengan menelusuri data-data atau dokumen terkait dengan pembahasan dalam penelitian. Teknik analisis menggunakan analisis regresi logistik dengan perangkat lunak SPSS v.26.

\section{HASIL DAN PEMBAHASAN}

Dalam model regresi logistik, pengujiannya diawali oleh uji kelayakan model regresi, dan dilanjutkan dengan uji keseluruhan model, uji matriks klasifikasi, uji koefisien determinasi dan uji hipotesis (Ghozali, 2018).

\subsection{Uji Kelayakan Model Regresi}

Uji kelayakan model regresi dilakukan dengan memanfaatkan fungsi Hosmer And Lemeshow's Goodness Of Fit Test. Uji ini ditujukan untuk menguji apakah model regresi yang terbentuk mampu atau layak digunakan untuk memprediksi pengaruh variabel independen terhadap variabel dependen. Atas pengujian Goodness of Fit Test menghasilkan data outlier yang menyebabkan bias pada hasil penelitian. Oleh karena itu, dilakukan identifikasi outlier melalui standardizes residual yang menjadikan jumlah pengamatan pada penelitian ini berkurang menjadi 105 amatan. Sehingga diperoleh hasil uji Goodness of Fit Test dengan nilai Chi-square sebesar 5,183 dengan signifikansi 0,521 yang menandakan bahwa penelitian ini layak dikarenakan model yang terbentuk cocok dengan data observasinya yakni signifikansi $>0,05 \quad(0,521>0,05)$.

\subsection{Uji Keseluruhan Model}

Fungsi log likelihood digunakan untuk melakukan pengujian keseluruhan model. Hasil pengujian diiketahui bahwa nilai -2 log likelihood (-2LL) pada awal (block number $=$ 0) yakni sebesar 96,210 dan nilai -2 log likelihood (-2LL) pada akhir (block number $=1$ ) yakni sebesar 45,083. Terjadinya penurunan pada nilai log likelihood (-2LL) menunjukkan bahwa model yang dihipotesiskan telah fit dengan data.

\subsection{Uji Matriks Klasifikasi}

Pengujian matriks klasifikasi digunakan untuk mengetahui seberapa besar tingkat ketepatan hasil prediksi model regresi logistik. Model yang baik memiliki tingkat akurasi yang mendekati 100\%. Hasil pengujian menunjukkan bahwa sebanyak 10 observasi $(55,6 \%)$ diprediksi akan memiliki kualitas audit yang rendah, sedangkan sebanyak 86 observasi $(98,9 \%)$ diprediksi akan memiliki kualitas audit yang tinggi. 
Secara keseluruhan tingkat akurasi klasifikasi hasil prediksi model regresi logistik yakni sebesar $91,4 \%$.

\subsection{Uji Koefisien Determinasi}

Pengujian koefisien determinasi pada model regresi logistik dilakukan dengan menggunakan Nagelkerke's $R$ Square. Hasil uji diperoleh nilai Nagelkerke's $R$ Square sebesar 0,642 atau 64,2\%. Hal ini berarti variabel dependen kualitas audit mampu dideskripsikan oleh variabel independen sebesar $64,2 \%$ sedangkan sisanya sebesar $35,8 \%$ merupakan kontribusi dari variabel lain yang tidak diulas dalam penelitian ini.

\subsection{Uji Hipotesis}

Tabel 2. Regresi Logistik

\begin{tabular}{cccccccccc}
\hline & & & & & & & \multicolumn{3}{c}{ 95\% C.I.for EXP(B) } \\
\cline { 6 - 9 } & & B & S.E. & Wald & df & Sig. & Exp(B) & Lower & Upper \\
\hline Step 1 $^{\text {a }}$ & X1 & 217.261 & 591.770 & .135 & 1 & .714 & $2.265 \mathrm{E}+94$ & .000 &. \\
& X2 & 16.689 & 7.829 & 4.544 & 1 & .033 & 17691752.363 & 3.837 & $8.157 \mathrm{E}+13$ \\
& X3 & -24.838 & 16.403 & 2.293 & 1 & .130 & $1.634 \mathrm{E}-11$ & .000 & 1498.996 \\
& M & 12.346 & 30.878 & .160 & 1 & .689 & 229967.025 & .000 & $4.413 \mathrm{E}+31$ \\
& X1M & -11.420 & 30.699 & .138 & 1 & .710 & 0.000011 & .000 & $1.486 \mathrm{E}+21$ \\
& X2M & -.650 & .314 & 4.270 & 1 & .039 & .522 & .282 & .967 \\
& X3M & .966 & .668 & 2.093 & 1 & .148 & 2.628 & .710 & 9.734 \\
& Constant & -240.242 & 596.219 & .162 & 1 & .687 & $4.616 \mathrm{E}-105$ & & \\
\hline
\end{tabular}

Sumber: Data diolah

Berdasarkan tabel 2, model regresi yang terbentuk dalam penelitian ini yakni sebagai berikut:

$$
\begin{aligned}
\operatorname{Ln} \frac{\text { kualitas }}{1-\text { kualitas }}= & -240,242+217,261 X_{1}+16,689 X_{2}-24,838 X_{3} \\
& 12,346 M-11,420 X_{1} M-0,650 X_{2} M+0,966 X_{3} M
\end{aligned}
$$

Hasil pengujian hipotesis dengan menggunakan uji wald berdasarkan tabel 2 diperoleh:

1. Nilai koefisien regresi positif Reputasi KAP $\left(X_{1}\right)$ sebesar 217,261 dan nilai statistik uji wald sebesar 0,135 dengan signifikansi 0,714>0,05, yang berarti $\mathrm{H}_{1}$ tidak dapat diterima.

2. Nilai koefisien regresi positif Audit Tenure $\left(X_{2}\right)$ sebesar 16,689 dan nilai statistik uji wald sebesar 4,544 dengan signifikansi $0,033<0,05$, yang berarti $\mathrm{H}_{2}$ diterima.

3. Nilai koefisien regresi negatif Auditor Switching $\left(\mathrm{X}_{3}\right)$ sebesar $-24,838$ dan nilai statistik uji wald sebesar 2,293 dengan signifikansi 0,130>0,05, yang berarti $\mathrm{H}_{3}$ tidak dapat diterima.

4. Nilai koefisien regresi negatif Audit fee sebagai pemoderasi reputasi KAP terhadap kualitas audit $\left(\mathrm{X}_{4}\right)$ sebesar $-11,420$ dan nilai statistik uji wald sebesar 0,138 dengan signifikansi $0,710>0,05$, yang berarti $\mathrm{H}_{4}$ tidak dapat diterima. 
5. Nilai koefisien regresi negatif Audit fee sebagai pemoderasi audit tenure terhadap kualitas audit $\left(\mathrm{X}_{5}\right)$ sebesar -0,650 dan nilai statistik uji wald sebesar 4,270 dengan signifikansi $0,039<0,05$, yang berarti $\mathrm{H}_{5}$ tidak dapat diterima.

6. Nilai koefisien regresi positif Audit fee sebagai pemoderasi auditor switching terhadap kualitas audit $\left(\mathrm{X}_{6}\right)$ sebesar 0,966 dan nilai statistik uji wald sebesar 2,093 dengan signifikansi 0,148>0,05, yang berarti $\mathrm{H}_{6}$ tidak dapat diterima.

\subsection{Pembahasan}

\section{Pengaruh Reputasi KAP terhadap Kualitas Audit}

Hasil penelitian menunjukkan reputasi KAP tidak berpengaruh terhadap kualitas audit. Hasil ini sesuai dengan hasil penelitian yang dilakukan oleh Novrilia et al., (2019), Aznedra \& Putra (2020) dan Darya \& Puspitasari (2017) yang menyatakan bahwa reputasi KAP tidak memiliki pengaruh terhadap kualitas audit sehingga KAP BigFour maupun KAP non BigFour berkemungkinan untuk menghasilkan kualitas audit yang tinggi. Adanya anggapan bahwa KAP BigFour akan menghasilkan kualitas audit yang tinggi daripada KAP non-BigFour tidak dibenarkan dikarenakan penugasan audit yang dilakukan oleh KAP BigFour maupun non-BigFour tentunya telah didasari oleh standar auditing dan kode etik profesi yang berlaku (Aznedra \& Putra, 2020). Selain itu, pengalaman, pemahaman dan skill yang memadai serta sikap professional dan independen yang dimiliki auditor dalam bertugas akan dapat menghasilkan kualitas audit yang baik meskipun auditor tersebut termasuk dalam KAP non-BigFour.

\section{Pengaruh Audit Tenure terhadap Kualitas Audit}

Hasil penelitian menunjukkan audit tenure berpengaruh positif dan signifikan terhadap kualitas audit. Hasil penelitian ini sesuai dengan penelitian yang dilakukan oleh Nugroho (2018), Ardani (2017) dan Lee \& Sukartha (2017) yang menyatakan bahwa audit tenure memiliki pengaruh positif terhadap kualitas audit, sehingga penunjukan auditor secara berkelanjutan oleh auditee dapat mempermudah auditor untuk memahami kompleksitas perusahaan sebab auditor telah mengetahui secara mendalam mengenai sistem pengendalian internal auditee. Menurut Irma et al., (2019), adanya perikatan antara KAP dengan auditee sebelumnya dapat mempermudah auditor untuk melaksanakan penugasan selanjutnya. Selain itu, masa perikatan yang panjang antara KAP dengan auditee akan membuat seorang auditor lebih memahami karakteristik bisnis auditee dan menjadikan auditor lebih teliti dan dapat mencegah terjadinya kecurangan, sehingga dapat menghasilkan kualitas audit yang lebih tinggi.

\section{Pengaruh Auditor Switching terhadap Kualitas Audit}

Hasil penelitian menunjukkan auditor switching tidak berpengaruh signifikan terhadap kualitas audit. Hal ini menunjukkan ada atau tidaknya pemberlakuan rotasi audit tidak akan berpengaruh terhadap kualitas audit karena penugasan audit oleh auditor didasarkan pada standar audit yang telah ditetapkan dan sikap profesionalisme. Hasil penelitian ini sesuai dengan penelitian yang dilakukan oleh Nizar (2017), Rahmi et al., (2019), Muliawan \& Sujana (2017) yang menyatakan bahwa auditor switching 
tidak memiliki pengaruh terhadap kualitas audit yang berarti bahwa tingginya kualitas audit tidak selamanya diiringi oleh adanya rotasi auditor dikarenakan auditor akan tetap mempertahankan independensinya dalam pelaksanaan audit sehingga kualitas audit yang dihasilkan akan tetap baik. Umumnya auditee akan melakukan rotasi audit ketika auditee mengalami ketidaksesuaian dan ketidakpuasan pada auditor dalam melaksanakan penugasan audit.

\section{Audit Fee Memoderasi Pengaruh Reputasi KAP terhadap Kualitas Audit}

Hasil penelitian menunjukkan audit fee tidak memoderasi pengaruh reputasi KAP terhadap kualitas audit. Menurut Dwiyani \& Rasmini (2017), tingginya biaya audit dapat meningkatkan kualitas audit sehingga perusahaan akan cenderung memilih menggunakan KAP yang bereputasi tinggi meskipun fee yang ditawarkan jauh lebih mahal dikarenakan adanya tingkat keahlian yang lebih tinggi. Namun faktanya, fee audit yang akan diterima oleh auditor telah disepakati saat sebelum pelaksaan penugasan audit sehingga jumlah fee yang diterima tidak akan mempengaruhi kualitas audit. Selain itu, baik KAP BigFour maupun non BigFour akan tetap bersikap objektif dan dapat mengungkapkan kondisi sesungguhnya terkait laporan keuangan auditee sehingga akan tetap menghasilkan kualitas audit yang baik (Irma et al., 2019).

\section{Audit Fee Memoderasi Pengaruh Audit Tenure terhadap Kualitas Audit}

Hasil penelitian menunjukkan audit fee memperlemah pengaruh audit tenure terhadap kualitas audit. Menurut Lee \& Sukartha (2017), tingginya biaya audit umumnya dapat meningkatkan keahlian dan kompetensi auditor mengenai kondisi bisnis auditee yang dapat menunjang auditor dalam melaksanakan penugasan audit sehingga dibutuhkan waktu perikatan yang lama agar dapat menghasilkan kualitas audit yang tinggi. Namun faktanya, hasil penelitian ini menyatakan bahwa audit fee memperlemah pengaruh audit tenure terhadap kualitas audit, artinya periode perikatan KAP dengan auditee yang semakin lama akan menaikkan biaya audit sehingga membuat manajemen perusahaan cenderung untuk melakukan perikatan dengan jangka waktu yang singkat agar biaya audit yang dikeluarkan tidak terlalu tinggi yang dilakukan untuk mencegah ketidaksanggupan auditee dalam membayar biaya audit yang tinggi. Namun, singkatnya masa perikatan akan menyebabkan pemahaman auditor mengenai auditee kurang sehingga kualitas audit yang dihasilkan dapat menurun.

\section{Audit Fee Memoderasi Pengaruh Auditor Switching terhadap Kualitas Audit}

Hasil penelitian menunjukkan audit fee tidak memoderasi pengaruh auditor switching terhadap kualitas audit. Penelitian ini sepaham dengan penelitian yang dilakukan oleh Lee \& Sukartha (2017) yang menyatakan bahwa audit fee tidak memoderasi pengaruh auditor switching terhadap kualitas audit, artinya ada atau tidaknya pergantian auditor kualitas audit yang dihasilkan akan tetap sama dikarenakan penugasan audit dilaksanakan sesuai dengan standar auditing yang berlaku tanpa memperhitungkan risiko fee yang akan diterima dikarenakan besaran fee yang akan dibayarkan telah disepakati saat awal pembuatan kontrak. Selain itu, pergantian 
auditor cenderung dilakukan oleh auditee jika auditee merasakan ketidakpuasan dan ketidaksesuaian pada auditor dalam pelaksanaan auditnya, bukan terkait dengan fee audit yang akan dibayarkan kepada auditor (Rahmi et al., 2019).

\section{PENUTUP}

Simpulan penelitian ini adalah reputasi KAP tidak berpengaruh secara signifikan terhadap kualitas audit. Audit tenure berpengaruh positif dan signifikan terhadap kualitas audit. Auditor switching tidak berpengaruh signifikan terhadap kualitas audit. Audit fee tidak memoderasi pengaruh reputasi KAP terhadap kualitas audit. Audit fee memperlemah pengaruh audit tenure terhadap kualitas audit. Audit fee tidak memoderasi pengaruh auditor switching terhadap kualitas audit.

Saran yang dapat peneliti berikan terkait penelitian ini yakni sebaiknya perusahaan dapat mempertimbangkan untuk melakukan perikatan dengan KAP dalam jangka waktu yang lama agar pemahaman auditor mengenai kondisi bisnis perusahaan semakin mendalam dan dapat menghasilkan kualitas audit yang tinggi. Auditor sebaiknya tetap menjaga independensi dan profesionalismenya dalam pelaksanaan penugasan audit serta melakukan perikatan dalam jangka waktu yang lama sehingga dapat meningkatkan pemahaman mengenai kondisi bisnis auditee sehingga dapat digunakan sebagai dasar pengambilan keputusan dan menghasilkan kualitas audit yang tinggi. Bagi peneliti yang akan datang dapat menggunakan variabel lain yang memiliki pengaruh terhadap kualitas audit seperti komite audit dan ukuran perusahaan.

\section{DAFTAR PUSTAKA}

Ardani, S. V. (2017). Pengaruh Tenure Audit, Rotasi Audit, Audit Fee Terhadap Kualitas Audit dengan Komite Audit Sebagai Variabel Moderasi (Studi pada Perusahaan Sektor Keuangan yang Terdaftar di BEI Tahun 2010-2014). Jurnal Akuntansi, 6(1), 1-12.

Aznedra, \& Putra, R. E. (2020). Pengaruh Audit Tenure Dan Reputasi Kap Terhadap Kualitas Audit Pada Perusahaan Indeks L45 Di Bursa Efek Indonesia Tahun 2015-2019. Jurnal Equilibiria, 7(1), 1-8.

Badan Pusat Statistik. (n.d.). PDB Seri 2010 (Miliyar Rupiah). Retrieved March 4, 2021, from Badan Pusat Statistik website: https://www.bps.go.id/indicator/11/65/2/-seri-2010-pdb-seri-2010.html

Darya, K., \& Puspitasari, S. A. (2017). Reputasi KAP, Audit Tenure, Ukuran Perusahaan Klien dan Kualitas Audit (Studi pada Perusahaan LQ 45 Indonesia). Jurnal Keuangan Dan Perbankan, 13(2), 97-109. Retrieved from http://journal.ibs.ac.id/index.php/jkp/article/view/49

De Angelo, L. E. (1981). Auditor Size And Audit Quality. Journal of Accounting and Economics, 3, 183-199.

Dwiyani, K., \& Rasmini, N. K. (2017). Fee Audit Sebagai Pemoderasi Pengaruh Auditor Switching Dan Audit Tenure Pada Kualitas Audit. E-Jurnal Akuntansi, 16(3), 2017-2043. 
Ghozali, I. (2018). Aplikasi Analisis Multivariate dengan Program IBM SPSS 25 (Edisi 9). Semarang: Badan Penerbit Universitas Diponegoro.

Hasanah, A. N., \& Putri, M. S. (2018). Pengaruh Ukuran Perusahaan, Audit Tenure Terhadap Kualitas Audit. Akuntansi, 5(1), 11-21.

Irma, F. A., Rispantyo, \& Kristianto, D. (2019). Pengaruh Audit Tenure, Rotasi Auditor, Reputasi Auditor, Dan Spesialisasi Auditor Terhadap Kualitas Audit. Jurnal Akuntansi Dan Teknologi Informasi, 14(5), 551-561.

Ishak, F. A. P., \& Perdana, H. D. (2015). Pengaruh Rotasi Audit, Workload Dan Spesialisasi Terhadap Kualitas Audit Pada Perusahaan Manufaktur Yang Terdaftar Di Bursa Efek Indonesia Pada Tahun 2009-2013. Jurnal Organisasi Dan Manajemen, 11(2), 183-194.

Jensen, M. C., \& Meckling, W. H. (1976). Theory of The Firm: Managerial Behavior, Agency Costs and Ownership Structure. Journal of Financial Economics, 305-360. https://doi.org/10.1016/0304-405X(76)90026-X

Kontan. (n.d.). Sektor Barang Konsumsi Jadi Jawara Sejak Awal Tahun. Retrieved March 4, 2021, from Kontan website: https://investasi.kontan.co.id/news/sektor-barang-konsumsi-jadi-jawara-sejakawal-tahun-simak-rekomendasi-analis-berikut-1

Lee, D., \& Sukartha, I. M. (2017). Fee Audit Sebagai Pemoderasi Pengaruh Auditor Switching dan Audit Tenure Pada Kualitas Audit. E-Journal Akuntansi Universitas Udayana, 18(2), 1455-1484.

Muliawan, E. K., \& Sujana, I. K. (2017). Pengaruh Ukuran Kantor Akuntan Publik, Auditor Switching Dan Audit Tenure Pada Kualitas Audit. E-Jurnal Akuntansi, 21(1), 534-561.

Mulyadi. (2016). Auditing 2 (6th ed.). Jakarta: Salemba Empat.

Nadia, N. F. (2015). Pengaruh Tenure KAP, Reputasi KAP dan Rotasi KAP Terhadap Kualitas Audit. Jurnal Akuntansi Bisnis, XIII(26), 113-130.

Nadya, D. (2020). Barang Konsumsi Tetap Dicari. Bisnis Indonesia, p. 10. Retrieved from

https://www.idx.co.id/StaticData/NewsAndAnnouncement/ANNOUNCEME NTSTOCK/From_EREP/202004/e272ecb198_e744436257.pdf

Nizar, A. A. (2017). Pengaruh Rotasi, Reputasi dan Spesialisasi Auditor Terhadap Kualitas Audit. Jurnal Nasional, XV(2), 157-172.

Novrilia, H., Arza, F. I., \& Sari, V. F. (2019). Pengaruh Fee Audit, Audit Tenure, dan Reputasi KAP Terhadap Kualitas Audit (Studi Empiris pada Perusahaan yang Terdaftar di Bursa Efek Indonesia Periode 2015-2017). Jurnal Eksplorasi Akuntansi, 1(1), 256-276. Retrieved from http://jea.ppj.unp.ac.id/index.php/jea/issue/view/2

Nugroho, L. (2018). Analisa Faktor-Faktor Yang Mempengaruhi Kualitas Audit (Studi Empiris pada Perusahaan Manufaktur Industri Sektor Barang Konsumsi yang Terdaftar Di Bursa Efek Indonesia tahun 2014-2016). Jurnal Maneksi, 7(1), 55. https://doi.org/10.31959/jm.v7i1.89 
Paputungan, R. D., \& Kaluge, D. (2018). Pengaruh Masa Perikatan Audit, Rotasi Audit Dan Ukuran Kantor Akuntan Publik Terhadap Kualitas Audit. Jurnal Reviu Akuntansi Dan Keuangan, 8(1), 93. https://doi.org/10.22219/jrak.v8i1.29

Permatasari, I. Y., \& Astuti, C. D. (2018). Pengaruh Fee Audit, Rotasi Auditor, Dan Reputasi Kap Terhadap Kualitas Audit. Jurnal Akuntansi Trisakti, 5(1), 81. https://doi.org/10.25105/jat.v5i1.4839

Pertamy, R. A. F., \& Lestari, T. (2018). Pengaruh Audit Tenure, Rotasi Audit Dan Reputasi Kap Terhadap Kualitas Audit (Studi Empiris Pada Perusahaan Manufaktur Sektor Industri Barang Konsumsi Yang Terdaftar Di Bursa Efek Indonesia Periode 2015-2017). Jurnal Riset Akuntansi Tirtayasa, 03(02), 159-175r.

Prasetya, I. F., \& Rozali, R. D. Y. (2016). Pengaruh Tenur Audit, Rotasi Audit Dan Reputasi Kap Terhadap Kualitas Audit (Studi Pada Perusahaan Manufaktur Yang Terdaftar Di Bursa Efek Indonesia Tahun 2011-2014). Jurnal ASET (Akuntansi Riset), 8(1), 39. https://doi.org/10.17509/jaset.v8i1.4020

Rahmi, N. U., Setiawan, H., Evelyn, J., \& Utami, Y. (2019). Pengaruh Audit Tenure, Spesialisasi Audit, Ukuran Perusahaan, dan Auditor Switching Terhadap Kualitas Audit pada Perusahaan Manufaktur Sektor Barang Konsumsi yang Terdaftar di Bursa Efek Indonesia. JIMEA: Jurnal Ilmiah MEA (Manajemen, Ekonomi, $\quad \mathcal{B} \quad$ Akuntansi, $3(3), \quad$ 40-52. https://doi.org/10.31955/mea.vol4.iss1.pp40

Ramadhan, I. N., \& Laksito, H. (2018). Pengaruh Reputasi Kantor Akuntan Publik ( Kap ), Audit Tenure, dan Biaya Audit Terhadap Kualitas Audit. Diponegoro Journal Of Accounting, 7(4), 1-13.

Rizki, S. M. (2020). Pengaruh Reputasi KAP, Ukuran KAP dan Biaya Audit Terhadap Kualitas Audit (Studi pada Perusahaan Manufaktur yang Terdaftar di BEI Tahun 2015-2017. Diponegoro Journal of Accounting, 9(3), 1-11.

Sugiyono. (2016). Metode Penelitian Pendidikan Pendekatan Kuantitatif, Kualitatif dan REDD. Bandung: CV. Alfabeta.

Tuanakotta, T. M. (2015). Audit Kontemporer. Jakarta: Salemba Empat. 